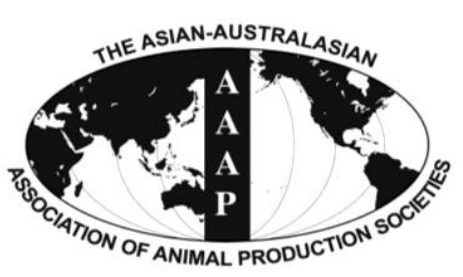

Open Access

Asian Australas. J. Anim. Sci.

Vol. 27, No. 11 : 1630-1637 November 2014

http://dx.doi.org/10.5713/ajas.2014.14187

www.ajas.info

pISSN 1011-2367 elSSN 1976-5517

\title{
Differences in Health-related Fatty Acids, Intramuscular Fat and the Physico-chemical Quality in Mutton as Affected by Season, Place of Purchase and Meat Portion
}

\author{
Zikhona T. Rani, Carlos W. T. Nantapo, Arnold Hugo ${ }^{1}$, and Voster Muchenje* \\ Department of Livestock and Pasture Science, University of Fort Hare, Eastern Cape 5700, South Africa
}

\begin{abstract}
The objective of the study was to determine the quality and fatty acid profiles of mutton cuts purchased from rural and urban localities in South Africa. Five hundred and ten samples were collected in four seasons from both rural and urban shops and butcheries. Samples were immediately transported to the laboratory in cooler boxes with ice where the following physico-chemical characteristics of mutton were determined; meat $\mathrm{pH}$, color $\left(\mathrm{L}^{*}, \mathrm{a}^{*}\right.$, and $\left.\mathrm{b}^{*}\right)$, cooking losses and Warner Braztler shear force and replicates stored at $-20^{\circ} \mathrm{C}$ pending fatty acid analysis. Meat $\mathrm{L}^{*}$ values were lowest $(24.7 \pm 0.49)$ in winter and highest (32.2 \pm 0.49$)$ in spring. The loin and sirloin cuts recorded the highest intramuscular fat whilst rib and leg cuts recorded the lowest intramuscular fat. In conclusion intramuscular fat, fatty acid profiles and physico-chemical quality of mutton were significantly affected by season and meat portion and not necessarily by the locality and class of shop. (Key Words: Place of Purchase, Season, Meat Quality, Fatty Acid Composition, Tenderness, Lightness)
\end{abstract}

\section{INTRODUCTION}

Throughout the history of mankind people have been raising and eating sheep as it is a dense source of nutrients that are vital for growth and development (Pereira and Vincente, 2013). In South Africa, recent statistics show a decrease in mutton consumption due to health worries related to its fat content (Sainsbury, 2009). The health conscious consumers consider the fat and saturated fatty acid (SFA) composition in mutton to be too high (Woods and Fearon, 2009). Evidence has shown an association between SFA and occurrence of cardiovascular diseases (Simopoulus, 2006). This has seen recent studies focusing on understanding the fatty acid profiles and improving individual fatty acids that convey good health to the consumer through various methods (Nantapo et al., 2014). Approaches used in improving fatty acid profiles include;

* Corresponding Author: Voster Muchenje. Tel: +27-40-602 2059, Fax: +27-86-628-2967, E-mail: vmuchenje@ufh.ac.za

${ }^{1}$ Department of Microbial, Biochemical and Food Biotechnology, University of the Free State, Bloemfontein 9300, South Africa Submitted Mar. 11, 2014; Revised May 20, 2014; Accepted Jun. 29, 2014 nutritional strategies (Wiecek et al., 2011), age grouping, portion selection (Schonfeldt and Strydom, 2011) and breed selection (Hoffman et al., 2005). However, the composition of fatty acids is also affected by season and region/place in which mutton is purchased (Muchenje et al., 2008). Few studies have described nutritional composition, including fatty acids profiles, of mutton sold to the public in rural and urban set-ups. Furthermore, most studies aim at analysing only the M. longissimus dorsi tissue yet there are so many retail cuts available in South Africa including chump, leg chop, loin chop, rib chop, shoulder chop, brisket chop and trotters (meat from foot).

In addition to fat and fatty acid indicators in meat there is need for careful consideration of other parameters by consumers. Physico-chemical parameters such as $\mathrm{pH}$, tenderness, colour, cooking loss (CL), flavour and juiciness of the meat should be considered as they are the most important determinants of meat quality which assist in understanding consumer expectations. In a study by Becker et al. (2000), the place of purchase was ranked high in assessing quality in the shop. Grunert (1997) and Vimiso et al. (2012) also found that consumers perceived the place of 
purchase as a crucial quality cue, with health conscious consumers preferring meat from upmarket cities. Therefore, it is important to determine if the place where consumers purchase meat and season have an effect on colour, CL and tenderness of the mutton cuts. The objective of this study was to determine the physico-chemical attributes, intramuscular fat (IMF), moisture content, fat free dry matter (FFDM) and fatty acid profiles of mutton cuts from different retailer type in South Africa.

\section{MATERIALS AND METHODS}

\section{Study site}

The study was conducted in five different municipalities situated in the Eastern Cape Province of South Africa. Selected areas were categorized based on population concentration and set-up into urban (high population density) and rural (low population density) towns. East London, King Williams Town and Queenstown were classified as urban while Alice, Middledrift, Peddie, Stutterheim, Cathcart, Adelaide, and Fort Beaufort were classified as rural towns. Therefore, place of purchase was either rural or urban.

\section{Experimental design}

Five hundred and ten samples were collected in four seasons i.e. summer (126 samples), autumn (132), winter (112) and spring (140), of the whole study period. Each sample is a make-up of the seven cuts/portions; chump, leg, loin, rib, shoulder, brisket chops, trotters. There were 62 urban and 64 rural samples collected in summer whilst 70 samples were collected in urban and 62 samples in rural towns during the autumn season. In winter, 58 samples were collected in urban towns whilst 54 samples were collected in rural towns. In spring, 65 samples were collected in rural towns whilst 75 samples were collected in urban towns. Each sample's portion/cut was equally divided into two parts. One part was immediately used for point of purchase determination of colour ( $\mathrm{L}^{*}, \mathrm{a}^{*}$, and $\left.\mathrm{b}^{*}\right), \mathrm{pH}, \mathrm{CL}$, and tenderness. The other part was immediately delivered to the laboratory in a cooler box containing ice at $\leq 4^{\circ} \mathrm{C}$ and stored at $-40^{\circ} \mathrm{C}$ awaiting IMF, proximate composition and fatty acid profile determination.

\section{Meat quality measurements}

Colour determination: Colour measurements were taken from the different cuts of mutton samples; chump, leg chop, loin chop, rib chop, shoulder chop, brisket chop and trotters at the point of purchase. The lightness $\left(\mathrm{L}^{*}\right)$, redness $\left(\mathrm{a}^{*}\right)$ and yellowness $\left(b^{*}\right)$ values (Commission International De I'Eclairage, 1976) were determined using a Minolta colourguide 45/0 BYK-Gardener GmbH machine, with a $20 \mathrm{~mm}$ diameter measurement area and illuminant D65-day light, $10^{\circ}$ observation angle. The guide was calibrated before each measurement using the green standard. Three readings were taken from each portion by rotating the instrument at $90^{\circ}$ between each measurement, in order to obtain a representative average value of the colour.

pH measurement: The $\mathrm{pH}$ of each cut/portion of the sample was determined using the Crison $\mathrm{pH} 25, \mathrm{pH}$ meter (Crison instruments, S.A., Alella, Spain) in the Meat Science laboratory at the University of Fort Hare. The $\mathrm{pH}$ meter was calibrated with $\mathrm{pH} 4$ and $\mathrm{pH} 7$ standard solutions. The $\mathrm{pH}$ and colour measurements were recorded on standard forms at $25^{\circ} \mathrm{C}$, room temperature.

Warner-Bratzler shear force and cooking loss determination: For determination of $\mathrm{CL}$ and WarnerBratzler shear force (WBSF) values, samples were taken out of the fridge a day before and were left to thaw at $25^{\circ} \mathrm{C}$, room temperature. Samples were weighed, labelled and placed in plastic bags before cooking in a water bath. Labelled samples were cooked for 45 minutes at $85^{\circ} \mathrm{C}$ (Yancey et al., 2010), cooled and weighed again to measure CL. Cooking loss was calculated using the following formula: $\mathrm{CL} \%=([$ weight before cooked - weight after cooked] $\div$ weight before cooked $) \times 100$.

After measurement of CL, the samples were then used to determine WBSF values. Three sub samples measuring $10 \mathrm{~mm}$ in diameter were cored parallel to the grain of the meat from each cut/portion. The samples were sheared perpendicular to the fibre direction using a Warner Bratzler (WB) shear device mounted on an Instron (Model 3344) Universal testing apparatus (cross head speed at $400 \mathrm{~mm} / \mathrm{min}$, one shear in the centre of each core). The mean maximum load $(\mathrm{N})$ was recorded for the batch.

Intramuscular fat, proximate composition and fatty acid analysis: Intramuscular fat, moisture content and FFDM were measured from the other half of the cut/portion stored. Total lipid fraction was extracted using the Soxhlet method for determination of fatty acids (AOAC, 2003). Total lipids from muscle samples were quantitatively extracted, according to the method of Folch et al. (1957), using chloroform and methanol in a ratio of 2:1. An antioxidant, butylate hydroxytoluene was added at a concentration of $0.001 \%$ to the chloroform: methanol mixture. A rotary evaporator was used to dry the fat extracts under vacuum and the extracts were also dried overnight in a vacuum at $50^{\circ} \mathrm{C}$, using phosphorus pentoxide as moisture adsorbent (Rani et al., 2011). Total extractable IMF was determined gravimetrically from the extracted fat and expressed as percent fat $(\mathrm{w} / \mathrm{w})$ per $100 \mathrm{~g}$ meat tissue. Fat free dry matter content was determined by weighing the residue on a preweighed filter paper, after drying. The moisture content was determined by subtraction (100\%-\%IMF-\%FFDM). Fatty acid methyl esters (FAMEs) were prepared for gas chromatography by methylation of the extracted fat, using 
methanol-BF 3 (12) and quantified using a Varian GX3400 GC with flame ionization detector, with a fused silica capillary column, Chrompack CPSIL88 (100 m length, 0.25 $\mathrm{mm}$ ID, $0.2 \mathrm{~mm}$ film thickness). Column temperature programme was 40 to $230^{\circ} \mathrm{C}$ (hold $2 \mathrm{~min} ; 4^{\circ} \mathrm{C} / \mathrm{min}$; hold 10 min). Fatty acid methyl ester samples were identified by comparing the retention times of FAME peaks from samples with those of standards obtained from Supelco (Supelco 37 Component Fame Mix 47885-U, SigmaAldrich Aston Manor, Pretoria, South Africa). The peak identified as conjugated linoleic acid (CLA) is for specific isomer $\mathrm{C} 18: 2 \mathrm{c} 9 \mathrm{t} 11$ (n-6) with the highest proportion over $75 \%$. Fatty acids were expressed as the proportion of each individual fatty acid to the total of all fatty acids present in the sample. The following fatty acid combinations and ratios were calculated by using the fatty acid data: total saturated fatty acids (SFA), total mono-unsaturated fatty acids, total polyunsaturated fatty acids (PUFA), total omega-6 fatty acids, total omega-3 fatty acids, PUFA/SFA and omega-6/omega-3 ratio.

\section{Statistical analysis}

The physico-chemical meat quality parameters $\left(\mathrm{pH}, \mathrm{L}^{*}\right.$, $\mathrm{a}^{*}$ and $\mathrm{b}^{*}, \mathrm{CL}, \mathrm{WBSF}$ values), IMF, moisture content, FFDM, individual and group fatty acids were analysed. A factorial experiment with three factors (Meat cut/portion, Effect of place where meat was purchased and Effect of season) was laid out in a randomised complete block design and Analysis of variance was calculated by PROC general linear model in SAS (Statistical Analysis Systems, 2011), using the following model:

$$
\begin{aligned}
\mathrm{Y}_{\mathrm{ijklmnop}}= & \mu+\mathrm{M}_{\mathrm{i}}+\mathrm{P}_{\mathrm{j}}+\mathrm{S}_{\mathrm{k}}+(\mathrm{M} \times \mathrm{P})_{1}+(\mathrm{P} \times \mathrm{S})_{\mathrm{m}}+(\mathrm{M} \times \mathrm{S})_{\mathrm{n}} \\
& +(\mathrm{M} \times \mathrm{P} \times \mathrm{S})_{\mathrm{o}}+\mathrm{E}_{\mathrm{ijk} \text { lmnop }}
\end{aligned}
$$

Where:

$\mathrm{Y}_{\mathrm{ijklmnop}}=$ Response variable $\left(\mathrm{L}^{*}, \mathrm{a}^{*}\right.$, and $\mathrm{b}^{*}, \mathrm{pH}, \mathrm{CL}$, tenderness, IMF, moisture content, FFDM, individual and group fatty acids)

$\mu=$ Overall mean common to all observations

$\mathrm{M}_{\mathrm{i}}=$ Meat cut/portion (chump, leg chop, loin chop, rib chop, shoulder chop, brisket chop, and trotters) rural)

$P_{j}=$ Effect of place where meat was purchased (urban or

$\mathrm{S}_{\mathrm{k}}=$ Effect of season (summer, winter, autumn and spring)

$(\mathrm{M} \times \mathrm{P})_{1}=$ Effect of Interaction between meat cut and place of purchase

$(\mathrm{P} \times \mathrm{S})_{\mathrm{m}}=$ Effect of interaction between place of purchase and season

$(\mathrm{M} \times \mathrm{S})_{\mathrm{n}}=$ Effect of interaction between meat cut and season

$(\mathrm{M} \times \mathrm{P} \times \mathrm{S})_{\mathrm{o}}=$ Effect of interaction between meat cut, place of purchase and season

$\mathrm{E}_{\mathrm{ijklmnop}}=$ Random error

Mean separation was conducted using the student T-test.

\section{RESULTS AND DISCUSSION}

\section{Effect of place of purchase on physico-chemical attributes of mutton}

According to Vimiso and Muchenje (2013), it is imperative for the meat industry to have knowledge on what quality cues consumers use when purchasing meat and how they can use this information to remain competitive. At the point of purchase consumers use intrinsic cues such as colour and extrinsic cues such as quality assurance, place of purchase and price (Becker et al., 2000). In a study by Becker et al. (2000), place of purchase was ranked as the most helpful in assessing meat quality in the shop. Grunert (1997) also indicated that consumers perceived the place of purchase as the most crucial quality cue followed by colour. Table 1 shows the effect of place of purchase on meat quality attributes at the point of purchase. There were no significant differences on $\mathrm{L}^{*}, \mathrm{a}^{*}, \mathrm{~b}^{*}$ values, $\mathrm{pH}$, and tenderness of the meat that was bought from urban and rural shops. This can be due to the fact that meat handling may be generally uniform within the industry especially when meat is fresh. However, the differences in CL may be as a result difference in storage environment and shelf time (Levy and Weitz, 1995).

\section{Effect of season on physico-chemical attributes}

Results of seasonal effects on physico-chemical attributes are presented in Table 2. There were significant seasonal effects $(\mathrm{p}<0.05)$ on the $\mathrm{L}^{*}$, tenderness, $\mathrm{pH}$, and $\mathrm{CL}$ of meat. However, $b^{*}$ and $a^{*}$ values of the meat were not affected by season. The $\mathrm{pH}$ was high in winter and autumn and low in summer and spring. These results were also reported by Gallo et al. (2009) in light lambs and could be due to high glycogen levels in muscles which is influenced

Table 1. Least square mean values $( \pm \mathrm{SE})$ for colour, $\mathrm{pH}$, tenderness and cooking loss of mutton from different place of

\begin{tabular}{|c|c|c|c|}
\hline Parameter & Urban & Rural & $\begin{array}{c}\text { Significance } \\
\text { level }\end{array}$ \\
\hline $\mathrm{n}$ & 265 & 245 & \\
\hline Lightness (L*) & $28.6 \pm 0.42$ & $28.8 \pm 0.50$ & NS \\
\hline Redness $\left(a^{*}\right)$ & $16.6 \pm 0.68$ & $15.1 \pm 0.81$ & NS \\
\hline Yellowness $\left(b^{*}\right)$ & $11.0 \pm 0.13$ & $10.8 \pm 0.16$ & NS \\
\hline $\mathrm{pH}$ & $6.0 \pm 0.02$ & $6.0 \pm 0.02$ & NS \\
\hline WBSF (N) & $19.2 \pm 0.45$ & $19.6 \pm 0.54$ & NS \\
\hline Cooking loss (\%) & $35.0^{\mathrm{a}} \pm 0.68$ & $32.0^{\mathrm{b}} \pm 0.81$ & $* *$ \\
\hline
\end{tabular}
purchase

SE, standard error; NS, not significant; WBSF, Warner-Bratzler shear force.

ab Means in the same row with different superscripts are significantly different $(\mathrm{p}<0.05)$. 
Table 2. Least square mean values $( \pm \mathrm{SE})$ for colour $\left(\mathrm{L}^{*}, \mathrm{a}^{*}\right.$, and $\left.\mathrm{b}^{*}\right), \mathrm{pH}$, tenderness and cooking loss of mutton in different seasons

\begin{tabular}{lcccc}
\hline & \multicolumn{3}{c}{ Season } \\
\cline { 2 - 5 } & Spring & Summer & Autumn & Winter \\
\hline $\mathrm{n}$ & 140 & 126 & 132 & 112 \\
Lightness $\left(\mathrm{L}^{*}\right)$ & $32.2^{\mathrm{a}} \pm 0.49$ & $26.9^{\mathrm{b}} \pm 0.49$ & $26.8^{\mathrm{b}} \pm 0.47$ & $24.7^{\mathrm{c}} \pm 0.49$ \\
Redness $\left(\mathrm{a}^{*}\right)$ & $17.8 \pm 0.85$ & $14.8 \pm 0.86$ & $15.3 \pm 0.81$ & $15.9 \pm 0.86$ \\
Yellowness $\left(\mathrm{b}^{*}\right)$ & $10.8 \pm 0.19$ & $10.9 \pm 0.19$ & $11.1 \pm 0.19$ & $10.7 \pm 0.19$ \\
$\mathrm{pH}$ & $5.9^{\mathrm{c}} \pm 0.02$ & $5.9^{\mathrm{c}} \pm 0.02$ & $6.2^{\mathrm{b}} \pm 0.02$ & $6.4^{\mathrm{a}} \pm 0.02$ \\
WBSF $(\mathrm{N})$ & $17.7^{\mathrm{c}} \pm 0.65$ & $20.7^{\mathrm{ab}} \pm 0.66$ & $37.7^{\mathrm{b}} \pm 0.63$ & $21.2^{\mathrm{a}} \pm 0.66$ \\
Cooking loss $(\%)$ & $28.8^{\mathrm{d}} \pm 0.88$ & $35.2^{\mathrm{b}} \pm 0.89$ & & $30.7^{\mathrm{c}} \pm 0.89$ \\
\hline
\end{tabular}

SE, standard error; WBSF, Warner-Bratzler shear force.

${ }^{\text {abcd }}$ Means in the same row without the same superscripts are significantly different $(\mathrm{p}<0.05)$.

by the fat-content of the feeding regime. The $\mathrm{L}^{*}$ values for meat purchased in winter were the lowest, showing a dark colour. Low $\mathrm{L}^{*}$ values in winter could be due to preslaughter cold stress. The cold stress in animals resulted in meat with a high ultimate $\mathrm{pH}$, low $\mathrm{L}^{*}$ values and dark colour in mutton samples purchased in winter. This is in line with results by Chulayo and Muchenje (2013) where mutton samples taken in the cold, wet season were darker than other meat samples from hot, wet season. According to Muchenje et al. (2008), high ultimate $\mathrm{pH}$ values are usually associated with dark cuttings. Mutton samples purchased in winter also had the highest values of WBSF values. Meat samples bought in summer and in autumn had the highest percentages of CL because during hot seasons since temperatures are high, there's higher thawing loss which results in high CL.

The $\mathrm{pH}$ of mutton samples purchased in winter and autumn in this study were between 6.2 and 6.4. Muchenje et al. (2008) stated that meat with $\mathrm{pH}$ above 6.0 is undesirable as it leads to dark firm dry meat. According to Hoffman et al. (2003), higher $\mathrm{pH}(>5.8)$ leads to undesirable meat colour which is unattractive to consumers. The colour of meat is determined by the relative amount of three myoglobin derivatives; i) reduced myoglobin, deoxymyoglobin $(\mathrm{Mb})$, which is the purple pigment of deep muscle and known from meat under vacuum, ii) oxygenated myoglobin, oxymyoglobin ( $\mathrm{MbO} 2)$, which is bright cherry red and considered to signify fresh meat by the consumer, and iii) oxidised myoglobin, metmyoglobin (MetMb), which is grey-brown (Rosenvold and Anderson, 2003). The type of packaging used in a shop affects the amount of oxygen exposure to the meat and will therefore influence the colour of meat and appeal to the customer. Different shops used different types of packaging namely; Vacuum packing, Overwrapping, and Frozen meat. In each packaging the temperature that the meat is stored under affects the quality of meat and this determines its shelf life (Davies, 1995).

\section{Effect of cut/portion on physico-chemical attributes}

Differences in the quality attributes of meat across different cuts were observed and depicted in Table 3 . There were significant differences between the different meat cuts in terms of colour, $\mathrm{pH}$, tenderness and CL. Higher values of $\mathrm{CL}$ and low values of WBSF were observed in the trotter, leg chop, and chump. Trotters had high values of $\mathrm{L}^{*}, \mathrm{a}^{*}, \mathrm{~b}^{*}$ values and $\mathrm{pH}$ as compared to other meat parts followed by the chump. The loin had the lowest $\mathrm{a}^{*}$ and L*values. The rib and sirloin chops had lowest WBSF values, indicating that they were softer as compared to other meat parts with rib being tougher. Rib chops had the lowest percentage values of CL. This is due to the fact that rib is made up of less muscle fibre. The difference in physico- chemical attributes corresponds to differences in muscle type and

Table 3. Least square mean values $( \pm \mathrm{SE})$ for colour, $\mathrm{pH}$, tenderness and cooking loss of mutton from different cut/portion

\begin{tabular}{lcccccc}
\hline Parameters & Lightness $\left(\mathrm{L}^{*}\right)$ & Redness $\left(\mathrm{a}^{*}\right)$ & Yellowness $\left(\mathrm{b}^{*}\right)$ & $\mathrm{Ph}$ & WBSF (N) & Cooking loss (\%) \\
\hline $\mathrm{n}$ & 510 & 510 & 510 & 510 & 510 & 510 \\
Brisket & $25.2^{\mathrm{c}} \pm 1.26$ & $15.6^{\mathrm{c}} \pm 0.62$ & $10.8^{\mathrm{cd}} \pm 0.49$ & $6.1^{\mathrm{b}} \pm 0.05$ & $22.8^{\mathrm{bc}} \pm 1.68$ & $31.9^{\mathrm{d}} \pm 1.98$ \\
Chump & $28.9^{\mathrm{a}} \pm 1.35$ & $15.0^{\mathrm{c}} \pm 0.67$ & $11.4^{\mathrm{c}} \pm 0.53$ & $6.2^{\mathrm{a}} \pm 0.06$ & $19.9^{\mathrm{d}} \pm 1.79$ & $35.1^{\mathrm{c}} \pm 2.13$ \\
Leg & $26.1^{\mathrm{b}} \pm 0.54$ & $15.8^{\mathrm{bc}} \pm 0.35$ & $10.9^{\mathrm{c}} \pm 0.21$ & $6.1^{\mathrm{b}} \pm 0.02$ & $19.2^{\mathrm{de}} \pm 0.72$ & $36.6^{\mathrm{bc}} \pm 0.85$ \\
Loin & $24.9^{\mathrm{d}} \pm 1.08$ & $14.7^{\mathrm{de}} \pm 0.53$ & $11.8^{\mathrm{bc}} \pm 0.42$ & $6.1^{\mathrm{b}} \pm 0.05$ & $21.5^{\mathrm{c}} \pm 1.43$ & $34.1^{\mathrm{c}} \pm 1.69$ \\
Rib & $25.1^{\mathrm{c}} \pm 0.71$ & $15.9^{\mathrm{b}} \pm 0.35$ & $10.4^{\mathrm{e}} \pm 0.28$ & $6.2^{\mathrm{a}} \pm 0.03$ & $18.9^{\mathrm{e}} \pm 0.94$ & $30.9^{\mathrm{d}} \pm 1.12$ \\
Shoulder & $26.9^{\mathrm{b}} \pm 0.59$ & $15.1^{\mathrm{c}} \pm 0.29$ & $10.9^{\mathrm{c}} \pm 0.23$ & $6.2^{\mathrm{ab}} \pm 0.03$ & $21.2^{\mathrm{c}} \pm 0.79$ & $34.0^{\mathrm{cd}} \pm 0.93$ \\
Sirloin & $25.3^{\mathrm{c}} \pm 1.60$ & $17.4^{\mathrm{a}} \pm 0.79$ & $10.5^{\mathrm{e}} \pm 0.63$ & $5.9^{\mathrm{c}} \pm 0.07$ & $18.9^{\mathrm{e}} \pm 2.13$ & $34.8^{\mathrm{c}} \pm 2.53$ \\
Trotter & $30.4^{\mathrm{a}} \pm 2.78$ & $30.4^{\mathrm{a}} \pm 2.78$ & $13.1^{\mathrm{a}} \pm 1.08$ & $6.3^{\mathrm{a}} \pm 0.12$ & $24.9^{\mathrm{b}} \pm 2.15$ & $39.5^{\mathrm{ab}} \pm 4.38$ \\
\hline
\end{tabular}

SE, standard error; WBSF, Warner Braztler Shear Force.

Means in the same column with different superscripts are significantly different $(\mathrm{p}<0.05)$. 
pigmentation between abdominal, pectoral, pelvic and thoracic mutton cuts. According to Muchenje et al. (2008), meat ultimate $\mathrm{pH}$ is widely used as an indicator of meat quality and carcasses are often categorised according to its $\mathrm{pH}$. Briefly, low $\mathrm{pH}_{\mathrm{u}}$ meat $\left(\mathrm{pH}_{\mathrm{u}}<5.8\right)$ is most ideal with regards to consumer acceptability and palatability and high $\mathrm{pH}_{\mathrm{u}}$ meat $\left(\mathrm{pH}_{\mathrm{u}}\right.$ 6.2) is darker in appearance and more susceptible to microbial spoilage. According to Gregory (2008), $\mathrm{pH}$ in mutton is expected to range between 5.75 and 6.00. Therefore, the observed $\mathrm{pH}$ in current study ranging from 5.9 to 6.3 could be considered to be on the higher and unacceptable. Cloete et al. (2008) reported that high $\mathrm{pH}$ has an effect on the colour and tenderness of the meat hence winter season was observed with high $\mathrm{pH}$ (6.4) values and high tenderness values. Meat tenderness has been reported to be related to ultimate $\left(\mathrm{pH}_{\mathrm{u}}\right)$ value and meat colour (Muchenje et al., 2008). Though one cannot predict tenderness of the meat at point of purchase, it is however, very important to acknowledge that a consumer would be willing to pay a higher price in the market place for meat as long as it is of guaranteed tenderness (Yancey et al., 2010).

\section{Effect of season, place of purchase and cut/portion on intra-muscular fat and proximate composition of mutton}

The results on the effect of season, place of purchase and mutton cut on intra-muscular fat, moisture content and FFDM are shown in Table 4. In the current study, rural and urban purchase points did not significantly influence moisture content, IMF and FFDM of mutton. However, significant differences observed in the moisture content, IMF and FFDM of mutton purchased in different seasons. Information on the proximate composition of raw mutton is important in evaluation of production and also nutrients retained by consumers (Schonfeldt and Strydom, 2011). Mutton purchased in the winter had the lowest moisture content, highest IMF and FFDM whilst mutton purchased in spring and summer recorded the highest moisture content and lowest IMF. Diet seems to be the contributing factor to fat levels in winter as concentrate supplementation helps improve fat content in winter. The inverse relationship between moisture and fat content was also observed by Cloete et al. (2008). Intramuscular fat content of raw meat influences sensory properties such as initial juiciness, sustained juiciness and first bite (Hoffman et al., 2005). Mutton of high IMF has high juiciness and is preferred by most consumers.

Mutton cuts were different in proximate composition. Loin and sirloin cuts recorded the highest IMF whilst rib and leg cuts recorded the lowest IMF. Similar observations were made by Sainsbury et al. (2009). Different muscles have different levels of fat and muscle build up leading to differences in fat marbling. It is due to this fat accumulation
Table 4. Effect of season, place of purchase and meat portion on intramuscular fat, moisture content and fat free dry matter of mutton

\begin{tabular}{lccc}
\hline & $\begin{array}{c}\text { Moisture } \\
\text { content }(\%)\end{array}$ & $\begin{array}{c}\text { Intramuscular } \\
\text { fat }(\%)\end{array}$ & $\begin{array}{c}\text { Fat free } \\
\text { dry matter }(\%)\end{array}$ \\
\hline Season & & & \\
Spring & $73.9^{\mathrm{b}} \pm 0.25$ & $4.0^{\mathrm{a}} \pm 0.21$ & $21.5^{\mathrm{a}} \pm 0.18$ \\
Summer & $73.9^{\mathrm{b}} \pm 0.25$ & $4.4^{\mathrm{a}} \mathrm{b} \pm 0.21$ & $21.7^{\mathrm{a}} \pm 0.18$ \\
Autumn & $73.5^{\mathrm{b}} \pm 0.19$ & $4.5^{\mathrm{b}} \pm 0.16$ & $22.0^{\mathrm{ab}} \pm 0.14$ \\
Winter & $72.6^{\mathrm{a}} \pm 0.26$ & $5.3^{\mathrm{c}} \pm 0.21$ & $22.3^{\mathrm{b}} \pm 0.18$ \\
p-value & 0.01 & 0.001 & 0.01 \\
Place of purchase & & & \\
Rural & $73.5 \pm 0.19$ & $4.5 \pm 0.16$ & $21.8 \pm 0.18$ \\
Urban & $73.4 \pm 0.16$ & $4.5 \pm 0.13$ & $21.9 \pm 0.10$ \\
p-value & $\mathrm{NS}$ & $\mathrm{NS}$ & $\mathrm{NS}$ \\
Cut/portion & & & \\
Brisket & $74.6^{\mathrm{b}} \pm 0.44$ & $3.7^{\mathrm{bc}} \pm 0.35$ & $21.6 \pm 0.30$ \\
Chump & $74.1^{\mathrm{b}} \pm 0.29$ & $4.1^{\mathrm{cd}} \pm 0.23$ & $21.7 \pm 0.19$ \\
Cutlets & $74.1^{\mathrm{b}} \pm 0.29$ & $3.2^{\mathrm{ab}} \pm 0.52$ & $22.7 \pm 0.44$ \\
Leg & $74.5^{\mathrm{b}} \pm 0.22$ & $3.6^{\mathrm{b}} \pm 0.18$ & $21.8 \pm 0.15$ \\
Loin & $71.3^{\mathrm{a}} \pm 0.30$ & $6.1^{\mathrm{e}} \pm 0.24$ & $21.4 \pm 0.20$ \\
Rib & $74.9^{\mathrm{b}} \pm 0.25$ & $2.9^{\mathrm{a}} \pm 0.20$ & $22.1 \pm 0.17$ \\
Shoulder & $73.9^{\mathrm{b}} \pm 0.21$ & $4.2^{\mathrm{cd}} \pm 0.17$ & $21.9 \pm 0.39$ \\
Sirloin & $69.7^{\mathrm{a}} \pm 0.57$ & $8.6^{\mathrm{f}} \pm 0.46$ & $21.9 \pm 0.39$ \\
Trotter & $74.1^{\mathrm{b}} \pm 0.56$ & $4.5^{\mathrm{d}} \pm 0.45$ & $21.7 \pm 0.38$ \\
p-value & 0.001 & 0.001 & $\mathrm{NS}$ \\
\hline NS, not & & &
\end{tabular}

NS, not significant

Least square means in same column for each description (season, place of purchase and meat portion) with different superscripts differ significantly.

that makes loin and sirloin a favourite cut to many consumers as they perceive it to be juicier than other cuts.

\section{Effect of place of purchase season on mutton fatty acid profiles}

Place of purchase did not significantly influence fatty acid profiles. However, fatty acid profiles differed according to season. The effect of season is summarized in Table 5. Oleic acid (38.4\%), palmitic acid (28.7\%) and stearic acid (16.3\%) dominated. Saturated fatty acids were highest in spring but lowest in winter. The levels of vaccenic acid, linoleic acid, linolenic acid, arachidonic acid, docosapentaenoic acid, DHA and lignoceric acid were lowest in winter and highest in spring. Monounsaturated and polyunsaturated fatty acids were also lowest in winter and highest in spring. This also corresponded with highest $n-3$ and $n-6$ fatty acids in winter and lowest composition in spring. Omega-3 and $n-6$ fatty acid are essential to human health (Simopoulus, 2002). Fatty acid composition in winter can impart a positive influence to health as SFAs are lower. These results were also reflected in the $n-6 / n-3$ ratio were the ratio was significantly lower in winter and highest in spring. The lowest ratio tends to support better cardiovascular health (Simopoulus, 2002). Results of $n-6 / n$ - 
Table 5. Effect of season on fatty acid profiles

\begin{tabular}{|c|c|c|c|c|}
\hline & Spring & Summer & Autumn & Winter \\
\hline $\mathrm{n}$ & 140 & 126 & 132 & 112 \\
\hline Vaccenic & $1.3^{\mathrm{b}} \pm 0.04$ & $1.2^{\mathrm{ab}} \pm 0.04$ & $1.2^{\mathrm{ab}} \pm 0.03$ & $1.1^{\mathrm{a}} \pm 0.04$ \\
\hline Linoleic & $5.0^{\mathrm{d}} \pm 0.27$ & $4.1^{\mathrm{b}} \pm 0.27$ & $4.8^{\mathrm{c}} \pm 0.21$ & $3.3^{\mathrm{a}} \pm 0.28$ \\
\hline CLA & $0.5 \pm 0.03$ & $0.5 \pm 0.03$ & $0.5 \pm 0.02$ & $0.5 \pm 0.03$ \\
\hline$\alpha$-Linolenic & $1.6^{\mathrm{b}} \pm 0.09$ & $1.5^{\mathrm{b}} \pm 0.09$ & $1.6^{\mathrm{b}} \pm 0.07$ & $1.2^{\mathrm{a}} \pm 0.09$ \\
\hline Arachidonic & $1.3^{\mathrm{b}} \pm 0.09$ & $0.9^{\mathrm{ab}} \pm 0.09$ & $1.2^{\mathrm{b}} \pm 0.07$ & $0.7^{\mathrm{a}} \pm 0.09$ \\
\hline Eicosatrienoic & $0.1 \pm 0.01$ & $0.1 \pm 0.01$ & $0.1 \pm 0.01$ & $0.1 \pm 0.01$ \\
\hline Heneicosanoic & $0.1 \pm 0.03$ & $0.1 \pm 0.01$ & $0.1 \pm 0.01$ & $0.1 \pm 0.01$ \\
\hline Oleic & $38.6^{\mathrm{ab}} \pm 0.51$ & $39.4^{\mathrm{b}} \pm 0.52$ & $37.7^{\mathrm{a}} \pm 0.39$ & $38.3^{\mathrm{ab}} \pm 0.52$ \\
\hline Docosapentaenoic & $0.5^{\mathrm{b}} \pm 0.03$ & $0.3^{\mathrm{a}} \pm 0.03$ & $0.4^{\mathrm{ab}} \pm 0.03$ & $0.3^{\mathrm{a}} \pm 0.03$ \\
\hline Docosahexanoic & $0.2^{\mathrm{b}} \pm 0.02$ & $0.2^{\mathrm{b}} \pm 0.02$ & $0.2^{\mathrm{b}} \pm 0.01$ & $0.1^{\mathrm{a}} \pm 0.02$ \\
\hline Lignoceric & $0.5^{\mathrm{c}} \pm 0.04$ & $0.3^{\mathrm{a}} \pm 0.04$ & $0.4^{\mathrm{b}} \pm 0.03$ & $0.3^{\mathrm{a}} \pm 0.04$ \\
\hline SFA & $48.8^{\mathrm{a}} \pm 0.49$ & $49.6^{\mathrm{a}} \pm 0.49$ & $50.1^{\mathrm{a}} \pm 0.37$ & $52.6^{\mathrm{b}} \pm 0.50$ \\
\hline MUFA & $42.2^{\mathrm{b}} \pm 0.51$ & $42.9^{\mathrm{b}} \pm 0.51$ & $41.2^{\mathrm{a}} \pm 0.41$ & $41.4^{\mathrm{a}} \pm 0.60$ \\
\hline PUF & $8.9^{c} \pm 0.43$ & $7.4^{\mathrm{b}} \pm 0.43$ & $8.7^{\mathrm{c}} \pm 0.33$ & $6.1^{\mathrm{a}} \pm 0.43$ \\
\hline$n 6$ & $6.7^{\mathrm{c}} \pm 0.35$ & $5.6^{\mathrm{b}} \pm 0.35$ & $6.5^{\mathrm{c}} \pm 0.27$ & $4.5^{\mathrm{a}} \pm 0.36$ \\
\hline$n 3$ & $0.2^{\mathrm{b}} \pm 0.01$ & $0.2^{\mathrm{b}} \pm 0.01$ & $0.2^{\mathrm{b}} \pm 0.01$ & $0.1^{\mathrm{a}} \pm 0.01$ \\
\hline PS & $0.2^{\mathrm{b}} \pm 0.01$ & $0.2^{\mathrm{b}} \pm 0.01$ & $0.2^{\mathrm{b}} \pm 0.01$ & $0.1^{\mathrm{a}} \pm 0.01$ \\
\hline$n 6 / n 3$ & $3.7^{\mathrm{b}} \pm 0.32$ & $3.6^{\mathrm{ab}} \pm 0.33$ & $3.6^{\mathrm{ab}} \pm 0.25$ & $3.5^{\mathrm{a}} \pm 0.33$ \\
\hline
\end{tabular}

CLA, conjugated linoleic acid; SFA, saturated fatty acids; MUFA, monounsaturated fatty acid; PUFA, polyunsaturated fatty acids; PS, polyunsaturated fatty acids/saturated fatty acids; $n-6 / n-3$, omega- 6 fatty acids/omega- 3 fatty acids; SE, standard error.

Least square means $\%( \pm \mathrm{SE})$ in the same row with different superscripts differ $(\mathrm{p}<0.05)$.

3 from this study were within a range (1.53 to 7.65) noted changes from pasture-based in summer to concentrateby Muchenje et al. (2008) even for grass-fed and grain-fed supplementation in drier winter months (Nantapo et al., animals. In all, the

fatty acid profiles are affected by the diet regime, which synthesis pathways.

Table 6. Effect of cut/portion on fatty acid profile of mutton

\begin{tabular}{|c|c|c|c|c|c|c|c|c|}
\hline & Brisket & Chump & Shoulder & Leg & Loin & Rib & Sirloin & Trotter \\
\hline $\mathrm{n}$ & 510 & 510 & 510 & 510 & 510 & 510 & 510 & 510 \\
\hline Vaccenic & $1.1^{\mathrm{ab}} \pm 0.07$ & $1.3^{\mathrm{b}} \pm 0.05$ & $1.2^{\mathrm{ab}} \pm 0.03$ & $1.3^{b} \pm 0.04$ & $1.2^{\mathrm{ab}} \pm 0.05$ & $1.2^{\mathrm{ab}} \pm 0.04$ & $1.0^{\mathrm{a}} \pm 0.09$ & $1.2^{\mathrm{ab}} \pm 0.10$ \\
\hline Linoleic & $4.4^{\mathrm{b}} \pm 0.47$ & $4.3^{b} \pm 0.31$ & $4.6^{\mathrm{bc}} \pm 0.22$ & $4.8^{\mathrm{bc}} \pm 0.24$ & $3.3^{\mathrm{ab}} \pm 0.32$ & $5.1^{\mathrm{c}} \pm 0.27$ & $2.7^{\mathrm{a}} \pm 0.61$ & $4.3^{b} \pm 0.59$ \\
\hline CLA & $0.5^{\mathrm{ab}} \pm 0.05$ & $0.6^{\mathrm{b}} \pm 0.03$ & $0.5^{\mathrm{a}} \pm 0.02$ & $0.5^{\mathrm{a}} \pm 0.02$ & $0.5^{\mathrm{a}} \pm 0.03$ & $0.5^{\mathrm{a}} \pm 0.03$ & $0.5^{\mathrm{ab}} \pm 0.06$ & $0.5^{\mathrm{ab}} \pm 0.06$ \\
\hline$\alpha$-Linolenic & $1.5^{\mathrm{b}} \pm 0.16$ & $1.2^{\mathrm{a}} \pm 0.10$ & $1.3^{\mathrm{ab}} \pm 0.07$ & $1.4^{\mathrm{b}} \pm 0.08$ & $1.3^{\mathrm{ab}} \pm 0.11$ & $1.9^{c} \pm 0.09$ & $1.3^{\mathrm{ab}} \pm 0.20$ & $1.3^{\mathrm{ab}} \pm 0.20$ \\
\hline Arach & $.1 \pm 0.01$ & $0.1 \pm 0.01$ & $0.1 \pm 0.01$ & $0.1 \pm 0.01$ & $0.1 \pm 0.01$ & $0.1 \pm 0.01$ & $0.1 \pm 0.02$ & $0.1 \pm 0.02$ \\
\hline & 0 & 0 & 0 & 0 & $0.1 \pm 0$ & $1+0$ & $0.1 \pm 0.10$ & $0.1 \pm 0.09$ \\
\hline Hene & $0.1 \pm 0.01$ & $0.1 \pm 0.01$ & $0.1 \pm 0.01$ & $0.1 \pm 0.01$ & $0.1 \pm 0.01$ & $0.1 \pm 0.01$ & $0.1 \pm 0.01$ & $0.1 \pm 0.01$ \\
\hline Oleic & $37.9^{\mathrm{a}} \pm 0.88$ & $39.4^{\mathrm{b}} \pm 0.58$ & $38.6^{\mathrm{ab}} \pm 0.42$ & $39.1 \pm 0.45$ & $39.3^{b} \pm 0.60$ & $37.3^{\mathrm{a}} \pm 0.51$ & $38.8^{\mathrm{ab}} \pm 1.15$ & $38.8^{\mathrm{ab}} \pm 1.12$ \\
\hline Docos & $0.4^{\mathrm{b}} \pm 0.06$ & $0.3^{\mathrm{ab}} \pm 0.04$ & $0.4^{\mathrm{b}} \pm 0.03$ & $0.4^{\mathrm{b}} \pm 0.03$ & $0.3^{\mathrm{ab}} \pm 0.04$ & $0.6^{\mathrm{c}} \pm 0.03$ & $0.2^{\mathrm{a}} \pm 0.08$ & $0.3^{\mathrm{ab}} \pm 0.07$ \\
\hline Doco & $0.1^{\mathrm{a}} \pm 0.03$ & $0.1^{\mathrm{a}} \pm 0.02$ & $0.1^{\mathrm{a}} \pm 0.01$ & $0.2^{\mathrm{b}} \pm 0.02$ & $0.1^{\mathrm{a}} \pm 0.02$ & $0.2^{\mathrm{b}} \pm 0.02$ & $0.2 \pm 0.07^{\mathrm{b}}$ & $0.1^{\mathrm{a}} \pm 0.04$ \\
\hline Lignoceric & $0.4^{\mathrm{b}} \pm 0.06$ & $0.3^{\mathrm{ab}} \pm 0.04$ & $0.4^{b} \pm 0.03$ & $0.4^{b} \pm 0.03$ & $0.3^{\mathrm{ab}} \pm 0.04$ & $0.6^{c} \pm 0.04$ & $02^{\mathrm{a}} \pm 0.09$ & $0.3^{\mathrm{ab}} \pm 0.09$ \\
\hline SFA & $50.1^{\mathrm{b}} \pm 0.84$ & $49.3^{\mathrm{ab}} \pm 0.55$ & $49.9^{\mathrm{b}} \pm 0.40$ & $48.6^{\mathrm{a}} \pm 042$ & $51.2^{\mathrm{c}} \pm 0.57$ & $49.8^{\mathrm{ab}} \pm 0.48$ & $52.8^{\mathrm{c}} \pm 1.09$ & $50.5^{\mathrm{b}} \pm 1.07$ \\
\hline MUFA & $41.2^{\mathrm{ab}} \pm 0.92$ & $43.1^{\mathrm{b}} \pm 0.61$ & $42.2^{\mathrm{ab}} \pm 0.44$ & $42.8^{\mathrm{ab}} \pm 0.47$ & $42.8^{\mathrm{ab}} \pm 0.62$ & $40.5^{\mathrm{a}} \pm 0.53$ & $42.2^{\mathrm{ab}} \pm 0.20$ & $42.1^{\mathrm{ab}} \pm 1.17$ \\
\hline PUFA & $8.0^{\mathrm{b}} \pm 0.73$ & $7.6^{b} \pm 0.48$ & $8.0^{\mathrm{b}} \pm 0.35$ & $8.6^{c} \pm 0.37$ & $6.1^{\mathrm{ab}} \pm 0.50$ & $9.7^{\mathrm{d}} \pm 0.42$ & $5.0^{\mathrm{a}} \pm 0.96$ & $7.5^{\mathrm{b}} \pm 0.93$ \\
\hline$n-6$ & $5.9^{b} \pm 0.60$ & $5.9^{\mathrm{b}} \pm 0.39$ & $6.2^{b} \pm 0.29$ & $6.6^{b c} \pm 0.30$ & $4.4^{\mathrm{a}} \pm 0.40$ & $7.0^{c} \pm 0.54$ & $3.5^{\mathrm{a}} \pm 0.78$ & $5.7^{\mathrm{b}} \pm 0.76$ \\
\hline$n-3$ & $2.1^{\mathrm{b}} \pm 0.22$ & $1.7^{\mathrm{a}} \pm 0.15$ & $1.8^{\mathrm{b}} \pm 0.11$ & $2.0^{\mathrm{b}} \pm 0.11$ & $1.6^{\mathrm{a}} \pm 0.15$ & $2.7^{\mathrm{c}} \pm 0.13$ & $1.5^{\mathrm{a}} \pm 0.29$ & $1.7^{\mathrm{a}} \pm 0.28$ \\
\hline PS & $0.2^{b} \pm 0.02$ & $0.2^{\mathrm{b}} \pm 0.01$ & $0.2^{\mathrm{b}} \pm 0.01$ & $0.2^{\mathrm{b}} \pm 0.01$ & $0.1^{\mathrm{a}} \pm 0.01$ & $0.2^{\mathrm{b}} \pm 0.01$ & $0.1^{\mathrm{a}} \pm 0.02$ & $0.2^{b} \pm 0.02$ \\
\hline$n-6 / n-3$ & $3.5^{\mathrm{ab}} \pm 0.56$ & $4.5^{c} \pm 0.37$ & $3.7^{\mathrm{b}} \pm 0.27$ & $4.4^{\mathrm{c}} \pm 0.28$ & $3.2^{\mathrm{ab}} \pm 0.38$ & $2.9^{\mathrm{a}} \pm 0.32$ & $2.9^{\mathrm{a}} \pm 0.73$ & $4.1^{b c} \pm 0.71$ \\
\hline
\end{tabular}

CLA, conjugated linoleic acid; SFA, saturated fatty acids; MUFA, monounsaturated fatty acid; PUFA, polyunsaturated fatty acids; PS, polyunsaturated fatty acids/saturated fatty acids; $n-6 / n-3$, omega- 6 fatty acids/omega- 3 fatty acids.

Least square mean values in the same row with different superscripts differ $(p<0.05)$. 


\section{Effect of cut/portion on mutton fatty acids}

The results on the effect of cut/portion on mutton fatty acids are shown in Table 6. Vaccenic, CLA, eicosatrienoic, heneicosanoic acids were not significantly different in meat portions. However, linoleic, linolenic, oleic, arachidonic, DPA, DHA were significantly affected by portion type. Ribs had the highest linoleic acid $(5.2 \pm 0.68$ and $5.1 \pm 0.27$ respectively), linolenic $(1.9 \pm 0.09$ and 1.9 \pm 0.23$)$, arachidonic (1.6 \pm 0.09 and $1.4 \pm 0.23)$ and DPA $(0.6 \pm 0.03$ and $0.05 \pm 0.08$ ). Generally, loin and sirloin cuts had the lowest DPA, linoleic acids giving an advantage to health as these fatty acids have a cholesterol reducing effect (Simopoulus, 2002; Woods and Fearon, 2009). However, these differences in cut have not been studied much in mutton cuts for us to give a more pronounced comparison.

\section{CONCLUSION}

In conclusion, place of purchase did not affect meat quality attributes and cannot be used as a good indicator of meat quality. However, season and cut/portion had an effect on fat content. Sirloin and loin cuts selected in winter season had the most favourable intra muscular fat content related to juiciness. In addition customers could also use the colour of mutton in selection of meat for domestic consumption. Differences in meat quality and fatty acid profiles of different mutton cuts were also observed. Promotion of health is complex issues as there is need to balance many nutrients especially fatty acids. Rib cuts are consistent with health promotion as $n-3 / n-6$ ratios are lower than any other mutton portions. Selection of these cuts in winter may influence better cardiovascular health.

\section{ACKNOWLEDGMENTS}

The authors would like to thank the Red Meat Research and Development (RMRD-SA) and the SA National Research Foundation (NRF) THRIP for financial support. Appreciation also goes to all the shops and butcher owners who participated in the study.

\section{REFERENCES}

AOAC. 2003. Association of Official Analytical Chemists. 3rd Ed. Quality Assurance Principles for Analytical Laboratorys. Washington, DC, USA.

Becker, T., E. Benner, and K. Glitsch, 2000. Consumer perception of fresh meat quality in Germany. Br. Food J. 102:246-266.

Chulayo, A. Y. and V. Muchenje. 2013. The effects of preslaughter stress and season on the activity of plasma creatine kinase and mutton quality from different sheep breeds slaughtered at a smallholder abattoir. Asian Austral. J. Anim. Sci. 26:1762-1772.

Cloete, J. J. E., L. C. Hoffman, and S. W. P. Cloete. 2008. Carcass characteristics and meat quality of progeny of five Merino dam lines crossed with Dormer and Suffolk sires. S. Afr. J. Anim Sci. 38:355-366.

Commission International De I'Eclairage (CIE). 1976. Colorimetry. 2nd edition. Vienna, Switzerland.

Davies, A. R. 1995. Advances in modified atmosphere packaging. In: New Methods of Food Preservation (Ed. G. W. Gould). Glasgow, Blackie, UK pp. 304-320.

Folch, J., M. Lees, and G. H. Sloane-Stanley. 1957. A simple method for the isolation and purification of total lipids from animal tissue. J. Biol. Chem. 226:497-509.

Gallo, S. B., E. R de Siqueira, E. F. Delgado, M. D. P. Silva, and G. T. Rosa. 2009. Influence of feeding regime and finishing system on lamb muscle fiber and meat quality. R. Bras. Zootec. 38:2204-2210.

Gregory, N. G. 2008. Animal welfare at markets and during transport and slaughter. Meat Sci. 80:2-11.

Grunert, K. G. 1997. What is steak? A cross-cultural study on the quality perception of beef. Food Qual. Pref. 8:157-174.

Hoffman, L. C., B. Kritzinger, and A. V. Ferreira. 2005. The effects of region and geneder on the fatty acid, amino acid, mineral, myoglobin and collagen contents of impala (Aepyceros melampus) meat. Meat Sci. 69:551-558.

Hoffman, L. C., M. Muller, S. W. P. Cloete, and D. Schmidt. 2003. Comparison of six crossbred lamb types: sensory, physical and nutritional meat quality characteristics. Meat Sci. 65:12651274.

Levy, M. and B. A. Weitz. 1995. Retailing Management. Richard D. Irwin, Inc., Chicago, IL, USA.

Muchenje, V., K. Dzama, M. Chimonyo, J. G. Raats, and P. E. Strydom. 2008. Meat quality of Nguni, Bonsmara and Aberdeen Angus steers raised on natural pasture in the Eastern Cape, South Africa. Meat Sci. 79:20-28.

Nantapo, C. T. W., V. Muchenje, and A. Hugo. 2014. Atherogenicity index and health related fatty acids in different stages of lactation from Friesian, Jersey and Friesian $\times$ Jersey cross cow milk under pasture-based dairy system. Food Chem. 146:127-133.

Pereira, P. M. C. C. and A. F. R. B. Vincente. 2013. Meat nutritional composition and nutritive role in the human diet. Meat Sci. 93:586-592.

Rani, Z. T., M. Chimonyo, A. Hugo, U. Marume, and V. Muchenje. 2011. Effect of parity on the proximate composition and fatty acid profile of milk from Nguni cattle grazing on natural pastures. Afr. J. Biotechnol. 10:8647-8653.

Rosenvold, K. and H. J. Andersen. 2003. Factors of significance for pork quality. A review. Meat Sci. 64:219-237.

Sainsbury, J. 2009. Nutrient Content and Carcass Composition of South African Mutton with a Focus on Bio-availability of Selected Nutrients. PhD. Thesis, University of Pretoria South Africa.

SAS. 2011. Users Guide, Version 9. Statistical Analysis System Institute Inc., Cary, NC, USA.

Schönfeldt, H. C. and P. E. Strydom. 2011. Effect of age and cut on cooking loss, juiciness and flavour of South African beef. Meat Sci. 87:180-190.

Simopoulus, A. P. 2002. The importance of the ratio of omega6/omega-3 essential fatty acids. Biomed. Pharmacother. 56: $365-379$. 
Simopoulus, A. P. 2006. Evolutionary aspects of diet, the omega6/omega-3 ratio and genetic variation: Nutritional implications for chronic diseases. Biomed. Pharmacother. 60:502-507.

Vimiso, P. and V. Muchenje. 2013. A survey on the effect of transport method on bruises, $\mathrm{pH}$ and colour of meat from cattle slaughtered at a South African commercial abattoir. S Afr. J. Anim. Sci. 43:105-111.

Vimiso, P., V. Muchenje, U. Marume, and R. Chiruka. 2012. Preliminary study on consumers and meat traders perceptions of beef quality and how the beef quality is affected by animal welfare practices. Sci. Res. Essays 7:2037-2048.
Wiecek, J., A. Rekiel, M. Batorska, and J. Skomial. 2011. Effects of restricted feeding and realimentation periods on pork quality and fatty acid profile of M. longissimus thoracis. Meat Sci. 87: 244-249.

Woods, V. B. and A. M. Fearon. 2009. Dietary sources of unsaturated fatty acids for animals and their transfer into meat, milk and eggs: A review. Livest. Sci. 126:1-20.

Yancey, J. W. S, J. K. Apple, J. F. Meullenet, and J. T. Sawyer. 2010. Consumer responses for tenderness and overall impression can be predicted by visible and near-infrared spectroscopy, Meullenet-Owens razor shear, and WarnerBratzler shear force. Meat Sci. 85:487-492. 